\title{
PERBANDINGAN KEJADIAN ANEMIA PADA REMAJA PUTRI YANG TINGGAL DI PONDOK PESANTREN DAN DI RUMAH DI MADRASAH ALIYAH PONDOK PESANTREN DARUSSALAM KEPUNG KEDIRI
}

\author{
Comparison Anemia In Adolescent Girls Who Stay At Pondok Pesantren And \\ At Home In Madrasah Aliyah Pondok Pesantren Darussalam Kepung Kediri
}

\author{
Eka Sri Purwandari \\ STIKES Karya Husada Kediri, Program Studi Kebidanan
}

\begin{abstract}
ABSTRAK
Anemia remaja masih menjadi masalah kesehatan di Indonesia. Kasus ini lebih banyak ditemukan pada remaja putri. Menstruasi yang dialami setiap bulan menjadi penyebab utama. Selain itu, perhatian berlebih terhadap penampilan fisik menjadi penyebab membatasi makan yang berujung pada berkurangnya nutrisi dan berdampak pada terjadianya anemia defisiensi gizi. Jauh dari orang tua dapat menyebabkan konsumsi makanan bergizi terbatas karena kurangnya kontrol maupun kemampuan dalam penyediaannya.Desain penelitian analitik menggunakan pendekatan potong lintang. Variabel bebas yaitu tempat tinggal remaja dan variabel terikat yaitu kejadian anemia. Populasi adalah remaja putri di Madrasah Aliyah Pondok Pesantren Darussalam Kepung Kediri dengan kriteria tidak dalam masa menstruasi dan tidak sakit saat penelitian yang ditentukan dengan tehnik simple random sampling dengan sampel sebanyak 105 responden. Waktu penelitian bulan Agustus 2016. Data tempat tinggal diperoleh dari wawancara dan kejadian anemia diukur dengan cyanmethaemoglobin. Analisa data menggunakan editing, coding, scoring dan tabulating. Uji statistik menggunakan chi square dengan bantuan SPSS versi 22. Hasil penelitian menunjukkan $\rho$ value sebesar $0,029<0,05$ yang berarti ada perbedaan kejadian anemia remaja putri antara yang tinggal di pondok dan di rumah. Remaja putri yang tinggal di pondok lebih banyak yang mengalami anemia disebabkan karena pada kurangnya pengetahuan, kurang kontrol dari orang tua dan kurangnya kemampuan atas ketersediaan makanan sehat.
\end{abstract}

Kata Kunci: Anemia, Remaja, Pondok Pesantrem

\begin{abstract}
Anemia of adolescent is a healthy problem in Indonesia. This case is more common in adolescent girls. Menstruation experienced every month is the main cause . In addition, excessive attention to physical appearance is a cause of limiting eating which results in reduced nutrition and results in the occurrence of nutritional deficiency anemia. Far from parents can cause consumption of nutritious food is limited due to lack of control and ability in providing it. Analytical research design used a cross-sectional approach. The independent variable were the place where adolescent girls living and the dependent variable were the incidence of anemia . The population were adolescent girls in the Pondok Pesantren Aliyah Darussalam Kepung Kediri with criteria not in menstruation and not sick when the research is determined by simple random sampling technique with a sample of 105 respondents . When the studied in August 2016. Data was obtained from questionnaire and anemia was measured by cyanmethaemoglobin. Data analysis used editing, coding, scoring and tabulating. Statistical test used chi square with software of SPSS version 22. The results showed $\rho$ value of $0.029<0.05$ which means that there were differences in the incidence of anemia among girls who lived in the cottage and at home. Adolescence girls who live in the cottage were more experienced anemia because lack of knowledge, lack of the parents's control and lack of on the availability of healthy foods.
\end{abstract}

Kata Kunci: Anemia, Teenagers, Boarding School 


\section{PENDAHULUAN}

Kelompok usia remaja merupakan kelompok rentan terjadi anemia. Riskesdas (2013) mengidentifikasi $35,1 \%$ anemia terjadi pada remaja dan $22,7 \%$ pada kelompok remaja putri usia 13-18 tahun. Hal ini wajar terjadi karena pada remaja putri setiap bulan mengalami menstruasi yang mengakibatkan kehilangan darah. Setiap terjadinya menstruasi selalu mengurangi volume darah sehingga berakibat terjadinya anemia (Arisman, 2014). Apalagi jika menstruasi yang dialami mengeluarkan darah banyak atau berlangsung lama (Nelson, 2015).

Anemia dikatakan sebagai kondisi hemoglobin darah menunjukkan kurang dari 12 gram/dl (WHO, 2011) dimana hemoglobin berfungsi mengikat oksigen. Akibatnya muncul rasa lemah, letih, lesu yang menjadi gejala umum pada penderita anemia (Dieny, 2012). Kondisi tubuh yang lemah menyebabkan semangat belajar menurun sehingga prestasi di sekolah pun menurun. Jika demikian masa depan remaja menjadi terancam.

Anemia remaja putri paling banyak ditemukan pada kekurangan gizi. Berdasarkan hasil penelitian Briawan dkk (2011) menyebutkan bahwa kelompok usia 13-15 tahu memiliki resiko terjadi anemia 2,73 kali daripada kelompok usia 10-13 tahun dan status gizi kurus mengalami anemia 8,32 kali status gizi gemu.

Kekurangan gizi pada remaja putri ini disebabkan pola makan yang salah karena dipengaruhi banyak faktor. Pola makan yang salah dan kurangnya pengetahuan gizi atau sengaja melakukan diet ketat untuk menjaga penampilannya sebagai kekhawatiran mengalami kegemukan. Kurangnya pengetahuan gizi seimbang merupakan penyebab utama anemia gizi. Perilaku yang cenderung diet ketat yang dilakukan remaja putri bukanlah tindakan yang tepat menjaga penampilan. Pembatasan terhadap makanan dapat dilakukan dalam bentuk makan sangat sedikit, melewatkan jam makan, atau bahkan berhenti memakan suatu jenis makanan tertentu seperti daging-dagingan menyebabkan berkurangnya sejumlah zat gizi penting yang dibutuhkan tubuh termasuk zat besi, asam folat dan vitamin C. Defisiensi pada zat gizi tersebut dapat menyebabkan terjadinya anemia.
Sebaliknya, ada pula yang disebabkan alasan ketidakmampuan untuk menyediakan makanan yang bergizi. Salah satu penyebab kondisi ini terjadi adalah faktor berjauhan dari orang tua karena alasan sekolah. Akhirnya harus tinggal mandiri menetap di tempat lain yang berjauhan dari rumah seperti asrama, pondok atau kos.

Penelitian menunjukkan kejadian anemia pada remaja putri sering ditemukan di lingkungan sekolah maupun lingkungan pondok pesantren. Sya'bian dan Sumarmi (2016) menemukan $57,5 \%$ remaja putri di pondok pesantren Darul Ulum Jombang mengalami anemia.

Seseorang yang tinggal menetap di pondok pesantren disebut santri atau santriwati. Kebanyakan santriwati termasuk dalam kelompok remaja yaitu usia 11-18 tahun. Remaja merupakan masa pertumbuhan dan perkembangan yang pesat. Adanya gangguan kesehatan pada masa remaja berpengaruh terhadap masa reproduksinya kelak. Remaja putri dengan anemia yang tidak tertangani akan memiliki resiko besar dalam kehamilan, persalinan, nifas dan bayi yang dilahirkannya.

Dari fenomena tersebut, maka peneliti tertarik melakukan penelitian tentang perbedaan kejadian anemia pada remaja putri yang tinggal menetap tinggal di pondok dan di rumah di Madrasah Aliyah (MA) Pondok Pesantren (Ponpes) Darussalam Kepung Kediri.

Penanganan anemia tidak cukup dilakukan oleh pemerintah bersama dinas kesehatan terkait tetapi memerlukan dukungan berbagai pihak dan peran serta masyarakat. Program pemberian tablet suplementasi $\mathrm{Fe}$ pada remaja putri di institusi pendidikan yang diberikan setahun sekali dari puskesmas hendaknya menjadi stimulasi bagi upaya mandiri masyarakat bagi tindak lanjut pencegahan anemia remaja putri. Penyuluhan oleh petugas kesehatan tentang anemia, bahaya dan pencegahannya perlu diberikan kepada para remaja secara aktif.

\section{METODE PENELITIAN}

Penelitian menggunakan desain analitik dengan pendekatan potong lintang yaitu penelitian pada variabel-variabel penelitian dilakukan dalam waktu yang bersamaan. 
Populasi dalam penelitian ini adalah seluruh remaja putri usia 15-18 tahun. Sampel penelitian ini adalah sebagian remaja putri yang memenuhi kriteria inklusi seperti bersedia menjadi responden, tidak menstruasi saat penelitian, tidak sakit, tidak diare atau menderita penyakit kronis sebesar 105 orang. Tehnik pengambilan sampel menggunakan simple random sampling

Penelitian dilaksanakan pada bulan Agustus 2016 di Madrasah Aliyah Pondok Pesantren Darussalam Kepung Kediri.

Setelah data terkumpul dilakukan editing, scoring, doding dan tabulating

Setelah hasil data masing-masing variable dibuat distribusi frekuensi selanjutnya dilakukan uji analitik untuk mengetahui adanya perbedaan kejadian anemia remaja putri yang tinggal di pondok dan di rumah dengan menggunakan chi square yang diolah menggunakan SPSS 22 .

\section{HASIL DAN PEMBAHASAN \\ Hasil}

1. Data Umum

Tabel 1. Distribusi Frekuensi Makan Remaja Putri Di MA Ponpes Darussalam Kepung Kediri

\begin{tabular}{ccc}
\hline Kategori & Frekuensi & Persentase \\
\hline 1 kali & 2 & 1.9 \\
2 kali & 83 & 79 \\
3 kali & 18 & 17,1 \\
$\geq 4$ kali & 2 & 1,9 \\
& 105 & 100 \\
\hline
\end{tabular}

Frekuensi makan remaja putri menunjukkan sebagian besar 2 kali sehari yang berarti kurang dari frekuensi yang seharusnya (3 kali).

Tabel 2. Distribusi Konsumsi Tablet Tambah Darah Remaja Putri Di MA Ponpes Darussalam Kepung Kediri

\begin{tabular}{ccc}
\hline Kategori & Frekuensi & Persentase \\
\hline Ya & 3 & 2,9 \\
Tidak & 102 & 97,1 \\
& 105 & 100 \\
\hline
\end{tabular}

Hampir seluruh remaja putri masih belum mengkonsumsi tablet tambah darah. Hal ini disebabkan belum mengetahui pentingnya tablet tmbah darah dalam menangani anemia.
Tabel 3. Distribusi Pantangan Makan Remaja Putri Di MA Ponpes Darussalam Kepung Kediri

\begin{tabular}{ccc}
\hline Kategori & Frekuensi & Persentase \\
\hline Ya & 22 & 21 \\
Tidak & 83 & 79 \\
& 105 & 100 \\
\hline
\end{tabular}

Pantangan makan dijumpai pada sebagian kecil remaja putri. Terutama pada makanan yang mengandung protein tinggi seperti telur, ayam maupun ikan-ikanan. Alasannya salah satunya karena alergi terhadap makanan tersebut.

2. Data Khusus

Tabel 4. Distribusi Tempat tinggal Remaja Putri Di MA Ponpes Darussalam Kepung Kediri

\begin{tabular}{ccc}
\hline Kategori & Frekuensi & Persentase \\
\hline rumah & 34 & 32,4 \\
pondok & 71 & 67,6 \\
& 137 & 100 \\
\hline
\end{tabular}

Data diatas menunjukkan remaja putri yang tinggal menetap di pondok lebih banyak daripada yang tinggal di rumah.

Tabel 5. Distribusi Kejadian Anemia Remaja Putri Di MA Ponpes Darussalam Kepung Kediri

\begin{tabular}{ccc}
\hline Kategori & Frekuensi & Persentase \\
\hline Anemia & 84 & 80 \\
Tidak & 21 & 20 \\
& 105 & 100 \\
\hline
\end{tabular}

Kejadian anemia ditemui pada sebagian besar remaja putri $(80 \%)$.

Tabel 6. Tabulasi silang Tempat Tinggal dengan Kejadian Anemia Remaja Putri Di MA Ponpes Darussalam Kepung Kediri

\begin{tabular}{|c|c|c|c|c|c|c|}
\hline Kejadian & \multicolumn{4}{|c|}{ tempat tinggal } & \multicolumn{2}{c|}{ Total } \\
\cline { 2 - 7 } Anemia & rumah & $\%$ & pondok & $\%$ & & $\%$ \\
\hline anemia & 23 & 21,9 & 61 & 58,1 & 84 & 80 \\
tidak & 11 & 10,4 & 10 & 9,6 & 21 & 20 \\
anemia & 34 & & 71 & & 105 & 100 \\
\hline Total & 34 & & & &
\end{tabular}

Hasil tabulasi silang hasil penelitian ini menunjukkan kejadian anemia sebagian besar dialami oleh remaja putri yang tinggal menetap di pondok. 
Hasil uji statistik dengan SPPS versi menunjukkan $\rho$ value sebesar $0,029<0,05$ yang artinya terdapat perbedaan yang bermakna pada kejadian anemia remaja putri yang tinggal menetap di pondok dan di rumah.

\section{PEMBAHASAN}

\section{Kharakteristik umum Responden}

Remaja putri yang belajar di MA Ponpes Darussalam Kepung Kediri terdiri dari dua kelompok yaitu yang menetap di pondok dan pulang ke rumah masing-masing setelah belajar di sekolah. Jumlah yang menetap di pondok lebih besar dari yang pulang ke rumah. Remaja putri yang tinggal di pondok berasal dari berbagai pelosok daerah yang tentunya jarang pulang ke rumah. Kondisi tersebut menyebabkan mereka harus mampu memenuhi kebutuhan sendiri dengan materi (uang) yang mereka dapatkan termasuk kebutuhan makan sehari-hari. Kebiasaan penyediaan makanan dikelola secara bersama tanpa ada pengawasan dari pihak ponpes.

Kebiasan makan pada remaja putri di MA Ponpes Darussalam Kepung Kediri ditemukan sebagian besar menunjukkan kurang baik. Hal ini banyak dijumpai dari frekuensi kurang dari 3 kali yaitu hanya 2 kali sehari yaitu pagi dan sore. Adapun upaya pencegahan anemia di tempat penelitian belum dilakukan karena hampir seluruh responden belum mengkonsumsi tablet tambah darah. Ditemukan sebagian kecil yang memiliki perilaku berpantang terhadap makanan tertentu dimana makanan tersebut dalam kategori makanan protein tinggi. Kondisi ini dapat menyebabkan kekurangan gizi.

\section{Kejadian Anemia Remaja Putri di Ponpes Darussalam Kepung Kediri}

Hasil penelitian menunjukkan

kejadian anemia terjadi pada sebagian besar remaja putri yang diteliti (80\%). Ini menunjukkan remaja putri memiliki resiko besar mengalami anemia. Secara fisiologis mereka mengalami kehilangan darah setiap bulan melalui menstruasi. Bersamaan dengan keluarnya darah, zat besi pun juga ikut hilang (Nelson et al, 2015).

Periode remaja merupakan masa pertumbuhan dan perkembangan yang pesat terjadi dimana membutuhkan zat besi yang adekuat (Evans, 2008). Zat besi penting bagi pertumbuhan fisik remaja sehingga kekurangan asupan zat besi berdampak terjadi anemia.

Anemia yang paling umum ditemukan pada remaja putri adalah anemia gizi. Anemia ini berhubungan erat dengan kekurangan zat gizi penting seperti zat besi, vitamin $\mathrm{C}$ dan asam folat. Zat gizi tersebut sebenarnya sangat mudah ditemukan pada berbagai makanan seperti sayuran hijau, telur, daging, kacang-kacangan, ikan, daging dan lain-lain (Arisman, 2013). Pola makan tidak benar berpengaruh terhadap asupan gizi. Pola makan dipengaruhi oleh persepsi remaja tentang makan dan persepsi ini terbentuk dari pengetahuan tentang gizi. Pola makan tersebut juga dipengaruhi karena pengetahuan gizi yang kurang (Alam, 2010). Variasi makanan yang kurang juga turut memberikan andil bagi asupan gizi yang kurang (Orinyiuka, et al, 2009).

\section{Perbedaan Kejadian Anemia Remaja Putri antara yang tinggal di Pondok dan di Rumah di Ponpes Darussalam Kepung Kediri}

Anemia erat kaitannya dengan kebiasaan makan. Kebiasaan makan seseorang dipengaruhi oleh kebiasaan lingkungannya. Remaja putri yang tinggal di rumah bersama orang tua memiliki kebiasaan makan yang sama seperti kebiasaan makan keluarganya terutama terkait frekuensi makan (Bau et al, 2011). Faktor lingkungan sangat penting dalam menentukan kebiasaan makan terutama peran ibu dalam menentukan menu harian di rumah (Pearson et al, 2012), sehingga asupan gizi untuk keluarga menjadi perhatian.

Hasil penelitian menunjukkan adanya perbedaan kejadian anemia pada remaja putri yang tinggal di pondok dan di rumah. Ini menunjukkan bahwa kondisi di dua tempat ini berbeda. Di rumah kebutuhan hidup remaja putri lebih terjamin ketersediaannya daripada mereka yang tinggal di pondok. Di rumah, kebutuhan fisik remaja putri terutama makan sudah disediakan oleh orang tua. Kondisi sebaliknya ditemukan pada mereka yang tinggal di pondok seperti harus menyiapkan sendiri makanan yang akan dikonsumsi setiap harinya bahkan harus mengadakan sendiri sebelum siap untuk dimasak dan disajikan. Belum lagi bagi mereka yang tinggal jauh dari orang tua harus mengatur keuangan yang mereka miliki agar 
dapat mencukupi keseluruhan kebutuhan mereka dalam jangka waktu tertentu.

Kebiasan makan remaja pun dapat menjadi faktor penyebab anemia pada mereka yang tinggal di pondok pesantren seperti frekuensi makan yang tidak ideal. Padahal frekuensi makan yang kurang dalam sehari dapat mempengaruhi asupan gizi mereka. Termasuk ragam makanan yang disajikan setiap harinya seharusnya menjadi perhatian. Jadi tidak asal makan yang penting kenyang. Kebiasaan makan remaja putri menggambarkan perilaku makan mereka. Faktor lingkungan dapat mempengaruhi perilaku makan seseorang (Pearson et al, 2012). Pengaruh lingkungan tersebut dimulai oleh peran ibu dalam menyajikan menu harian di rumah maupun teman atau kelompok saat beraktivitas bersama di luar rumah. Bau et al (2011) juga membenarkan bahwa kondisi lingkungan tempat tinggal sangat berpengaruh terhadap kebiasaan makan remaja putri. Remaja putri yang tinggal bersama orang tua lengkap, ibu saja maupun tanpa orang tua memiliki kebiasaan makan yang berbeda dalam frekuensi makan.

Variasi makanan harian diperlukan guna memenuhi gizi seimbang. Pada mereka yang memiliki kecenderungan mengkonsumsi makanan sumber protein nabati saja tanpa mengimbangi dengan sumber protein hewani (vegetarian) sering dijumpai kondisi anemia. Begitu pula bagi mereka yang memiliki pantangan terhadap jenis makanan tertentu dapat juga mengalami kekurangan gizi apabila makanan tersebut merupakan makanan sumber zat besi.

Fenomena diatas sangat sering ditemukan pada remaja putri mandiri yang tinggal jauh dari orang tua. Apalagi kurang adanya pengetahuan yang memadai tentang pentingnya gizi bagi tubuh. Pengetahuan gizi ini sangat diperlukan dalam pencegahan anemia. Haryanti (2016) menemukan adanya perbedaan pengetahuan gizi pada remaja yang mengalami anemia dan tidak. Ini menunjukkan pengetahuan gizi yang dimiliki remaja putri dapat memberi gambaran kepada remaja putri. Balarajan et al (2011) menemukan anemia remaja putri di India terjadi pada kelompok sosial ekonomi menengah ke bawah memiliki hubungan dengan ketidaktahuan tentang anemia dan gizi.
Meskipun demikian, remaja yang jauh dari orang tua memiliki sikap kemandirian yang jauh lebih baik daripada yang tinggal dengan orang tua. Oleh karena pengetahuan tentang gizi dan anemia sangat dibutuhkan remaja putri dalam menyiapkan makanan untuk memenuhi kebutuhan mereka. Demikian pula pembiasaan makan yang baik sangat diperlukan bagi remaja putri yang tinggal terpisah dengan orang tua. Roustit_et al (2011) mengemukakan bahwa kebiasaan yang ditanamkan orang tua kepada anak-anak memberikan pengaruh besar pada kesehatan di kemudian hari. Kondisi keluarga ikut memberikan kontribusi terhadap kebiasaan anak. Kebiasaan anak inilah yang akan terbawa sampai dewasa bahkan turut menentukan status kesehatan.

\section{SIMPULAN DAN SARAN \\ Simpulan}

Ada perbedaan kejadian anemia pada remaja putri yang tinggal menetap di pondok pesantren dan di rumah di Ponpes Darussalam Kepung Kediri. Faktor kurangnya pengetahuan tentang gizi dan bahaya anemia, kurangnya kontrol dari orang tua dan kurangnya ketersediaan makanan yang bergizi menjadi alasan terjadinya anemia pada remaja putri yang tinggal di pondok pesantren.

\section{Saran}

Perlunya dilakukan tindakan pencegahan anemia pada remaja putri dengan melibatkan seluruh pihak terkait.

Pemberian tablet $\mathrm{Fe}$ setiap tahun sekali sebagai salah satu program kesehatan reproduksi remaja dalam menangani anemia perlu dilakukan secara berkesinambungan dan merata ke semua institusi yang terdapat remaja putri didalamnya. Hal ini diharapkan mampu menjadi stimulus bagi tindakan mandiri yang dapat dilakukan remaja putri bersama pihak sekolah atau pondok pesantren.

\section{DAFTAR PUSTAKA}

Alam N et al (2010) Nutritional Status, Dietary Intake, and Relevant Knowledge of Adolescent Girls in Rural Bangladesh. Journal of Health, Population and Nutrition. 28 (1): 8694. 
Arisman (2014). Gizi dalam daur kehidupan. Jakarta: EGC

Balarajan Y, Ramakrisnan U, Ozaltin E, Shankar AH, Subramanian SV.(2011). Anaemia in low-income and middle-income countries. Lancet. 378:2123-35

Bau AM et al (2011). Eating behaviour and its association with social living conditions and weight status among adolescent girls: results of the crosssectional Berlin School Children's Cohort study. Public Health Nutrition 14 (10) ): 1759-67.

Bhakta, I.M. (2006). Hematologi Klinik Ringkas. Jakarta : EGC

Briawan D, Arumsari E, Pusporini (2011). Faktor Risiko Anemia Pada Siswi Peserta Program Suplementasi(Risk Factors of Anemia in School Girls Participant of Supplementation Program). Jurnal Gizi dan Pangan. 2011. 6 (1): 74-83

Dieny, FF (2014). Permasalahan Gizi pada remaja putri. Yogjakarta: Graha Ilmu.

Evans M. (2008). Iron deficiency through the female life cycle - who needs to care?. Midirs Midwifery Digest. 18(3):404-8

Haryanti, S (2016). Perbedaan pengetahuan Gizi Tentang Anemia dan Angka Kesakitan antara Siswi Anemia dan Non Anemia di SMK Penerbangan Bina Dhirgantara Karanganyar. Naskah Publikasi.program Studi Ilmu Gizi Fakultas Ilmu Kesehatan Universitas Muhamadiyah Surakarta.

Irianto, K (2014). Gizi seimbang dalam kesehatan reproduksi. Bandung : Alfabeta

Onyiriuka AN et al. (2013). Snack consumption pattern among adolescent Nigerian urban secondary school girls. International Journal of Child and Adolescent Health . 6 (3): 311-317
Pearson, $\mathrm{N}$ et al. (2012) Maternal and best friends' influences on meal-skipping behaviours. The British Journal of Nutrition. 108 (5) : 932-8.

Riskesdas. 2013. Penyajian pokok- pokok Hasil Riset Dasar Kesehatan RI 2013. Badan Penelitian dan Pengembangan Kesehatan Kementrian Kesehatan RI.

Roustit C et al (2011) Family social environment in childhood and selfrated health in young adulthood. BMC Public Health .11 : 949.

Sya'bani, I.; Sumarmi, S. (2016). Anemia pada Santriwati di Pondok pesantren Darul Ulum Jombang. Jurnal Keperawatan Muhammadiyah 1(1)

WHO. 2011. Haemoglobin concentrations for the diagnosis of anaemia and assessment of severity. World Health Organization : Geneva 